\title{
NEG1 CONSTRUCTIONS IN OLD ENGLISH
}

\author{
MASAYUKI OHKADO \\ Chubu University
}

\begin{abstract}
In NEG first (NEG1) constructions, which are frequently observed in Old English, the negating particle ne occupies a "sentence initial" position and is immediately followed by a finite verb. Since the negating particle is analyzed as cliticized to the finite verb, NEG1 constructions apparently seem to be instances of verb first sentences, which are occasionally observable in Old English. This article will show that in spite of their appearance NEG1 constructions should be analyzed as verb second, but not verb first constructions. Specifically, it will be argued that in the constructions the initial position is occupied by an empty operator and that the combination of the negating particle and finite verb is in the second position.*
\end{abstract}

\section{Introduction}

The aim of this article is to present an analysis of Old English negative constructions which will be referred to as NEG first (NEG1) constructions. They are illustrated in (1), where the negating particle $n e$ 'not' immediately followed by a finite verb occupies a sentence initial position.

(1) a. Ne forseah Crist his geongan cempan not despised Christ his young champions 'Christ did not despise his young champions'

(ÆCHom I, 82. 33)

b. Ne mæg he nane gesceafta gescyppan not can he no creatures create 'He can create no creatures' (ÆCHom I, 16. 20-21) Specifically, it will be shown that such examples as (1) should be analyzed as verb second, but not verb first constructions, with the first

* I am grateful to Kozo Kato, Willem Koopman, Kikuyo Ohkado, and two anonymous $E L$ reviewers for their invaluable comments on an earlier version of this paper. All remaining errors and inadequacies are, of course, my own.

English Linguistics 13 (1996) 277-298 - 277 -

(C) 1996 by the English Linguistic Society of Japan 
position being occupied by an empty operator and the second position by the combination of negating particle $n e$ and finite verb.

The paper is organized as follows. Section 2 will introduce the analytic framework which is adopted in the present study. Section 3 will demonstrate that the Old English negating particle ne is to be treated as an $\mathrm{X}^{0}$ category which cliticizes to finite verbs. Section 4 will introduce two possible analyses of NEG1 constructions. The first analysis, which will be called the V1 analysis, treats NEG1 constructions as instances of verb first constructions. On the other hand, the second analysis, which will be referred to as the V2 analysis, postulates the presence of an empty element in NEG1 constructions and treat them as verb second sentences. Section 5 will present three pieces of evidence supporting the V2 analysis introduced in the preceding section. One of them is theory-internal and the other two are empirical. Section 6 is a conclusion.

In this study the first series of AElfric's Catholic Homilies (ed. by Thorpe (1844)) is used as a database.

\section{Analytic Framework}

Aside from specific details, I adopt the analysis of Old English proposed by Van Kemenade (1987). The clause structure of Old English assumed here is (2), where VP is head-final. ${ }^{1}$

1 The internal structure and the position of $I$ is controversial. Kato (1989), Koopman (1990: ch. 1), Pintzuk (1991, 1993), and Saito et al. (1991) argue, for example, that IPs in Old English can be head-initial so that the clause structure of Old English can be as in (i).

(i)

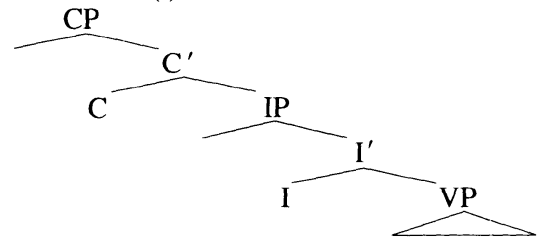

The split INFL structure proposed in Pollock (1989) is adopted by Ishikawa (1995), Kageyama (1992), and Tanaka (1994) and INFL in (i) is split into AGR and Tense. Even two AGRs are assumed in Haeberli (1991), Haeberli \& Haegeman (1995), and Roberts (1993).

For the sake of simplicity I adopt the "standard" analysis here, but the choice does not affect the discussion in the present paper. 
(2)

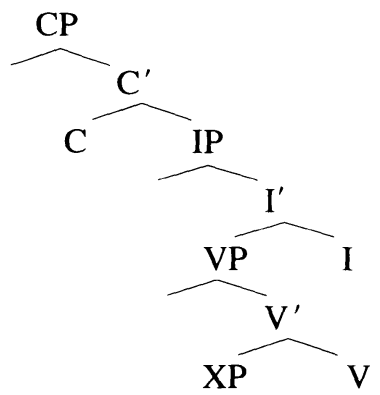

In main clauses a topic or focus element ( $w$ h-words, some adverbs) and the finite verb, respectively, move to the Spec $\mathrm{C}^{\prime}$ and $\mathrm{C}$ positions so that the well-known verb second phenomena are observed, as illustrated in (3). ${ }^{2}$

2 It is standardly assumed that topic elements in verb second languages are in the Spec $C^{\prime}$ position (see Vikner (1995) and references cited there), and Van Kemenade's (1987) analysis of Old English is in accordance with this tradition. In contrast, recent works such as Müller \& Sternefeld (1993) and Zwart (1993) argue that $w h$-movement and topic movement should be differentiated with respect to the landing site of the fronted elements. This is the position taken by Kiparsky (1995) and Pintzuk (1991).

Kiparsky (1995) assumes that the generation of $\mathrm{C}$ and its projections are optional in Old English so that its clause structure can be either (ia) or (ib).

(i) a. $\left[\mathrm{CP}\left[\mathrm{C}^{\prime} \mathrm{C}[\mathrm{s} \ldots .].\right]\right]$

b. $[s \quad \ldots .$.

(ia) is only generated in restricted cases such as interrogative sentences, where operators move into the Spec $C^{\prime}$ position. In contrast, the structure of sentences without operators is (ib) and topic elements are adjoined to $\mathrm{S}$. This analysis, however, seems to make a wrong prediction: Topicalization is not accompanied with $\mathrm{V}$-to-C movement unless the relevant sentence contains an operator. (ii) is the expected structure in Kiparsky's (1995) framework.

(ii) [s topic [s Subject [vp ...]]]

Investigation of the present text shows that topicalization is predominantly accompanied with subject-verb inversion unless subject is pronominal. Of the 38 examples of NP topicalization in clauses with a full NP subject, for instance, only two $(5.3 \%)$ fail to cooccur with inversion. (iii) is one of the two examples.

(iii) Đyllice word Maria heold aræfnigende on hire heortan such words Mary held pondering in her heart 'Mary held such words pondering in her heart' (ÆCHom I, 42. 30) In other words, only two examples exhibit the order illustrated in (ii), which shows that Kiparsky's (1995) analysis cannot handle most of the examples.

In the present framework, (iii) will be dealt with by assuming that the initial element is adjoined to $\mathrm{CP}$ and the Spec $\mathrm{C}^{\prime}$ position is occupied by the subject as illustrated in (iv). 
(3) a. topic $=$ subject

Manega lease Cristas cumað on minum naman many false Christs come in my name

'Many false Christs will come in my name'

(ÆCHom I, 4. 2)

b. $\quad$ topic $=$ object

Mycel yfel deð seðe leas writ

great evil does he-who false writes

'Those who write false do great evil'

(ÆCHom I, 8. 12-13)

c. $\quad$ topic $=\mathrm{PP}$

$B e$ his geðafunge gecyrde se apostol ongean

with his consent returned the apostle against

mid micclum wurðmynte

with great worship

'With his consent the apostle returned with great worship'

d. topic $=$ adverb

(ÆCHom I, 60.6-7)

Forðy sealde God mannum gescead

therefore gave God men reason

'therefore God has given reason to men'

(ÆCHom I. 96. 13)

e. topic $=$ adjective

Ydel bið se læcedome be ne mæg ðone

vain is the medicine which not can the

untruman gehælan

sick heal

'The medicine which cannot heal the sick is vain'

(ÆCHom I, 60. 33-34)

(iv) $\left[\mathrm{CP}\right.$ Object $\left[\mathrm{CP}_{\mathrm{P}}\right.$ Subject $\left.\left.\left[\mathrm{C}^{\prime} \mathrm{V}[\mathrm{IP} \ldots]\right]\right]\right]$

Thus, the difference between operator movement and topicalization is that, while the fronted element obligatorily moves to the Spec $C^{\prime}$ position in the former, it may optionally be adjoined to $\mathrm{CP}$ in the latter.

Adopting Santorini's (1989) analysis of Yiddish, Pintzuk (1991, 1993) claims that topicalized elements occupy the Spec $I^{\prime}$ position and that the Spec $C^{\prime}$ position is available only for operators. The most serious problem with this approach is that it fails to account for the crucial difference between Yiddish and Old English: While the former is a general embedded V2 language as Santorini's (1989) analysis predicts, the latter is a limited embedded V2 language contrary to the prediction Pintzuk's (1991, 1993) analysis makes (cf. Ohkado (1996)). 
With respect to the trigger of V-to-C movement, following Safir (1982) and Travis (1984), I assume (4). ${ }^{3}$

(4) V-to-C movement is triggered when the Spec $\mathrm{C}^{\prime}$ position is filled.

\section{3. $N e$ as a Clitic}

As pointed out by Mitchell (1985: $§ \$ 1599-1602)$, the negating particle $n e$ in Old English is almost exclusively positioned immediately before a finite verb ${ }^{4}$ and it is analyzed as a clitic by Ishikawa (1995), Van Kemenade (1985), Ohkado (1989), and Traugott (1992). This analysis is supported by the following facts.

First, contraction phenomena are observed when $n e$ is used with some verbs as exemplified in (5).
( 5 ) a. ne + hæfde $\Rightarrow$ næfde
Næfde he pæt andgit ðurh mæglice
not-had he the intelligence through parental
lare
teaching
'He did not have that intelligence through parental teaching'

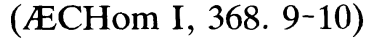
b. $\quad$ ne + is $\Rightarrow$ nis
Nis nan man god butan Gode anum not-is no man good except God only
'No man is good except God only'

(ÆCHom I, 254. 8-9)

c. ne + wæron $\Rightarrow$ næron

Næron hi swa-ðeah ealle endemes

not-were they however all equally

3 Various alternative analyses have been proposed in the literature for V-to-C movement in Germanic languages. Holmberg (1986) and Taraldsen (1986) claim that V-to-C movement takes place because $C^{0}$ must acquire the $[+V]$ feature of fronted verbs. Hulk and Van Kemenade (1995), Koopman (1984) and Platzack (1986) attribute V-to-C movement to Case-theoretic reasons. De Haan and Weerman (1986), Holmberg and Platzack (1995), Rizzi (1990), Roberts (1993), and Tomaselli (1990) claim that V-to-C movement is triggered by an element in $C^{\circ}$ position. An analysis in terms of the license of VP by $\mathrm{C}$ is proposed in Weerman (1989). See Vikner (1995: 51-80), where previous analyses and their problems are conveniently summarized.

4 This statement does not apply to ne used as a conjunction. 


\section{ungeleaffulle}

unbelieving

'However, they were not all equally unbelieving'

(ÆCHom I, 108. 25)

d. ne + wat $\Rightarrow$ nat

Nat nan man ðone dæg ne ðone timan ðysre not-knows no man the day nor the time this worulde geendunge

world's ending's

'No man knows the day or the time of the ending of this world'

(ÆCHom I, 298. 14-15)

e. ne + wille $\Rightarrow$ nelle

Nelle we ðas race na leng teon

not-will we this narrative no longer extend

'We will not longer extend this narrative'

(ÆCHom I, 88. 32)

Second, the application of V-to-C movement cannot leave the placement of ne unaffected. Thus, whenever finite verbs are fronted, ne is fronted as well so that such a derivation as illustrated in (6b) is not allowed.

(6) Crist his geongan cempan ne forseah

Christ his young champions not despised $\Rightarrow V$-to-C

a. [ne forseah $]_{i}$ Crist his geongan cempan $t_{i}$

b. ${ }^{*}$ forsea $_{\mathrm{i}}$ Christ his geongan cempan $n e \mathrm{t}_{\mathrm{i}}$

This is in sharp contrast with other elements. The object NP geongan cempan 'young champions' in (1a), for example, is unaffected by the movement of the finite verb forseah 'despise.'

Third, ne may appear in a position where no other XP elements occur. Consider the following subordinate clause examples, where modal verbs with infinitival complements are involved and the latter precedes the former.

(7) a. pæt he pone halgan biscop mid bam geleaffullan that he the holy bishop with the faithful folce adylegian sceolde

folk destroy might 'that he might destroy the holy bishop with the faithful folk'

(ÆCHom I, 562-564. 35-1)

b. bæt hi binnan ðam fyrste his halgan lichaman that they within the time his holy body 


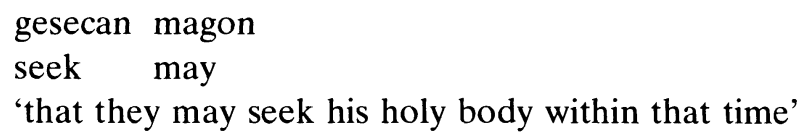

(ÆCHom I, 564. 25-26)

As pointed out by Koopman (1992) and Pintzuk (1991), in such constructions no element may intervene between nonfinite and modal verbs, with the exception of the negating particle ne. This statement holds true of our text, the first series of AElfric's Catholic Homilies as well. (8) are examples with $n e$ intervening between a nonfinite and modal verbs.
( 8 ) a. ponne he hi dælan ne mæg when he them distribute not can 'when he cannot distribute them' (ÆCHom I, 66. 6)
b. pæt nanes mannes gesihð pæs leohtes leoman that no man's sight the light's rays sceawian ne mihte see not could 'that no man's sight could see the rays of light'

(ÆCHom I, 76. 11-12)

The exceptional character of $n e$ is accounted for under the assumption that $n e$ cliticizes to the following finite verb so that it is not regarded as an intervening element. It might be assumed that the process is an instance of incorporation, whereby $\mathrm{V}$ is adjoined to the negating particle as illustrated in (9).

(9)

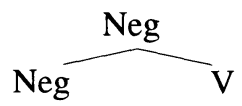

The extended version of Emonds's (1976) Structure-Preserving Hypothesis (cf. Chomsky (1986)), which states that the category adjoined to a head must be a head, leads us to the conclusion that the negating particle is an $\mathrm{X}^{0}$ element since it adjoins to $\mathrm{V}$, which is another $\mathrm{X}^{0}$ element.

Following Pollock (1989), I assume the NegP analysis, which is also adopted for Old English by Haeberli (1991), Haeberli and Haegeman (1995), Ishikawa (1995), and Roberts (1993). The structure of Old English negative sentences assumed here is (10), where the negating particle ne occupies the head position of the NegP. ${ }^{5}$

5 The structure in (10) is in accordance with Ohkado's (1989) proposal that Neg precedes I in languages with head-final IPs. 
(10)

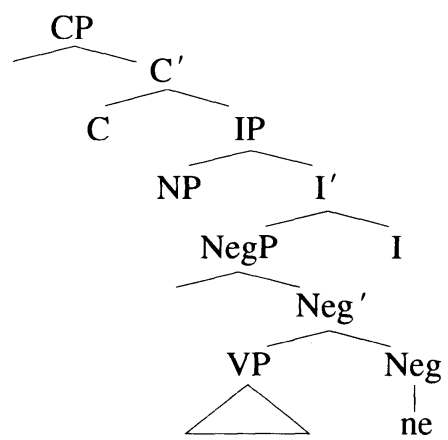

V-to-I movement is mediated by V-to-Neg movement in accordance with the Head Movement Constraint proposed in Baker (1988) and Travis (1984), ${ }^{6}$ and the ' $n e+$ finite verb' combination is created.

\section{Clitic Analysis of $\mathrm{Ne}$ and Its Consequences}

Once the clitic analysis of ne advocated in the preceding section is adopted, there are two possible analyses of the configuration of NEG1 constructions.

The first analysis is to regard NEG1 constructions as instances of verb first sentences. Let us call it the verb first (V1) analysis. It treats NEG1 constructions in parallel fashion with such V1 constructions as in (11).

(11) a. Comon eac sume ða ungeleaffullan, mid nanum came also some the unbelieving with no wurðmynte, ac mid micclum graman honors but with great anger 'Some who did not believe also came with no honors, but with great anger'

b. Beah ða ungerim folces to converted then countless-number folk's to cristendome burh Petres lare Christianity through Peter's teaching 'Then, countless numbers of people converted to Christianity through Peter's teaching'

(ÆCHom I, 374. 30-31)

The second analysis, which will be called the verb second (V2)

6 Chomsky (1991) reduces the Head Movement Constraint to the ECP. 
analysis, treats NEG1 constructions in parallel fashion with other V2 constructions as illustrated in (12).

a. $(=(3 a))$

Manega lease Cristas cumað on minum naman many false Christs come in my name 'Many false Christs will come in my name'

(ÆCHom I, 4. 2)

b. $\quad(=(3 b))$

Mycel yfel deð seðe leas writ great evil does he-who false writes

'Those who write false do great evil'

(ÆCHom I, 8. 12-13)

This approach assumes that the difference between ordinary V2 constructions and NEG1 constructions is that the element occupying the Spec $C^{\prime}$ position is empty in the latter case while it is overt in the former.

(13a) and (13b), respectively, illustrate the structures assigned to NEG1 constructions in the V1 and V2 analyses.

(13) a. structure of (1a) in the V1 analysis

[CP $\left[\mathrm{C}^{\prime}\right.$ ne-forseah ${ }_{\mathrm{i}}$ [IP Crist his geongan cempan $\left.\left.\mathrm{t}_{\mathrm{i}}\right]\right]$

b. structure of (1b) in the V2 analysis [CP $\mathrm{O}$ [C $\mathrm{C}^{\prime}$ ne-forseah ${ }_{\mathrm{i}}$ [IP Crist his geongan cempan $\left.\mathrm{t}_{\mathrm{i}}\right]$ ]

While the Spec $C^{\prime}$ position in (13a) is empty, it is occupied by an empty element ' $O$ ' in (13b). I assume that ' $O$ ' in (13b) is an empty operator.

The presence of an empty operator in negative sentences is independently motivated by the NEG-criterion proposed in Haegeman (1995). The NEG-criterion is given in (14).

(14) NEG-criterion

a. A NEG-operator must be in a Spec-head configuration with an $\mathrm{X}^{0}$ [NEG];

b. An $X^{0}$ [NEG] must be in a Spec-head configuration with a NEG-operator.

(Haegeman (1995: 106))

Recall that in the present analysis the negating particle $n e$ is an $\mathrm{X}^{0}$ category. The second statement of the NEG-criterion requires that it should be in a Spec-head relation with a NEG-operator. This requirement is satisfied by the presence of either overt or empty operators in the Spec Neg' position. Consider such examples as (15), where $n e$ is used with other negative adverbs. 
(15)
a. heo ne geendað næfre
it not ends never
'it will never end'

b. forðan ðe he nis na Scyppend

(ÆCHom I, 16. 16-17/ Mitchell (1985: §1604))

because he not-is no Creator

'because he is not God' (ÆCHom I, 16.21/ibid.)

In these examples negative adverbs are generated in the Spec Neg' position as illustrated in (16) and the NEG-criterion is satisfied.

(16)

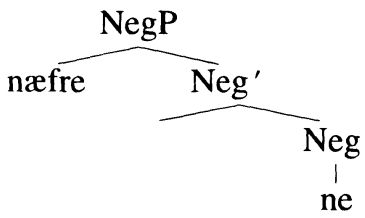

In cases where other negative adverbs are not used the NEG-criterion is satisfied by the presence of an empty operator in the Spec Neg' position as illustrated in (17).

(17)

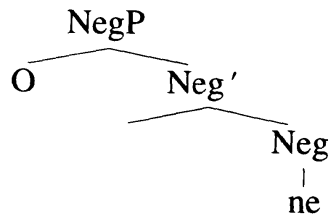

In Old English, where the negating particle always leaves its basegenerated position and is attached to finite verbs, the NEG-criterion is satisfied by the presence of its trace in the $\mathrm{Neg}^{0}$ position, which is in a Spec-head relation with an operator, or the trace of an operator when the latter also undergoes movement, in the Spec Neg' position. The V2 analysis claims that in NEG1 constructions the empty NEG operator is moved to the Spec $C^{\prime}$ position.

In this connection note that the analysis of NEG1 constructions advocated by Van Kemenade (1987: 139) cannot be maintained. The structure of the relevant constructions in her analysis is given in (18). ${ }^{7}$

(18) a [CP ne [ $\mathrm{C}^{\prime}$ forseah $\mathrm{h}_{\mathrm{i}}$ [IP Crist his geongan cempan $\left.\left.\mathrm{t}_{\mathrm{i}}\right]\right]$ The structure in (18) is in violation of Chomsky's (1986) Structure Preserving Hypothesis since ne, which is an $\mathrm{X}^{0}$ element, occupies a

7 The structure in (18) is slightly modified so that it fits the present framework. 
position for an XP element.

Ouhalla (1990) suggests that languages vary with respect to the lexical realization of the NegP elements. In Standard French, for example, the head as well as the specifier is realized lexically. In Turkish and Berber only the head is realized lexically and the specifier position is occupied by an empty operator. In German, Swedish, and Colloquial French it is the specifier that is realized lexically and the head position is occupied by an abstract morpheme.

Old English is a hybrid between the first and the second type: In this language the lexical realization of the specifier is optional while the head is always lexically realized. The picture is completed by adding the fifth type of language, a hybrid between the first and the third, where the realization of the head is optional whereas that of the specifier is obligatory. The situation is summarized in (19). ${ }^{8}$

(19) realization of the Neg elements

$\begin{array}{lll} & \text { head } & \text { specifier } \\ \text { Standard French } & \text { yes } & \text { yes } \\ \text { Old English } & \text { yes } & \text { yes /no } \\ \text { Turkish, Berber } & \text { yes } & \text { no } \\ \text { West Flemish } & \text { yes / no } & \text { Yes } \\ \text { Colloquial French, } & \text { no } & \text { Yes } \\ \text { German, Swedish } & & \end{array}$

\section{Evidence for the V2 Analysis}

This section will present three pieces of evidence which support the $\mathrm{V} 2$ analysis of NEG1 constructions. One of them is theory-internal and the other two are empirical. Let us first consider the theoryinternal evidence.

A theoretical advantage of the V2 analysis is that we can maintain our assumption (4), repeated here as (20) for convenience, in NEG1 constructions.

(20) V-to-C movement is triggered when Spec $C^{\prime}$ position is filled.

8 The treatment of not in Present-day English is controversial. It is analyzed as an $\mathrm{X}^{0}$ element in Ishikawa (1995) and Roberts (1993). On the other hand, Haegeman (1995) analyzes it as a specifier. Note that Haegeman (1995) analyzes the contracted form $n$ ' $t$ as an $\mathrm{X}^{0}$ element. 
In contrast, the V1 analysis should treat NEG1 constructions as exceptions to the rule.

The second piece of evidence is concerned with the frequency of V1 constructions in contrast with that of NEG1 constructions. Of 4642 main clauses in the first series of Alfric's Catholic Homilies there are 28 V1 constructions. In contrast, there are as many as 169 NEG1 constructions. Note that these figures do not include the constructions given in (21)-(23) although finite verbs appear in sentence initial position there.

(21) interrogative sentences

Eart ðu Andreas

are you Andrew

'Are you Andrew'

(22) constructions with an extraposed subject ${ }^{9}$

(ÆCHom I, 588. 4)

Wearð ða gebiged eal Francena rice to Godes

was then converted all Franks' realm to God's geleafan

faith

'Then all the realm of the Franks was converted to God's faith'

(ÆCHom I, 560. 12-13)

(23) constructions with no nominative subject

a. imperative sentences

Lufiað eowere fynd

love your enemies

'Love your enemies'

(ÆCHom I, 56. 8-9)

b. constructions with a clause subject (or impersonal)

Is nu geleaflic bæt se heah-engel Michahel hæbbe is now credible that the archangel Michael has

gymene cristenra manna

care Christian men's

'It is now credible that the archangel Michael has care of Christian men'

(ÆCHom I, 518. 26-27)

9 Since nonfinite verbs do not undergo leftward movement, the "nonfinite verbsubject" order must be derived by subject extraposition. See also Kato (1995) for subject extraposition in Old English. 
c. constructions with a deleted subject

Com ba to his apostlum

came then to his apostles

'Then, (Christ) came to his apostles' (ÆCHom I, 28. 5)

If NEG1 constructions are to be handled in parallel fashion with V1 constructions, why is the frequency of the former six times as high as that of the latter? This remains unexplained. On the other hand, the V2 analysis of NEG1 constructions gives a natural account for the frequency difference. According to the V2 analysis NEG1 constructions are regarded as instances of V2, but not V1 patterns. Since V2 sentences are by far the most frequent patterns in Old English, the high frequency of NEG1 constructions is expected. In our text there are 2873 V2 patterns. $^{10}$

The third piece of evidence supporting the V2 analysis is related to categorial restrictions imposed on the type of finite verbs that are used in V1 constructions. In our text finite verbs that are used in V1 constructions are restricted to the following set.

wesan, and weorðan 'be' (20 examples)

a. is heo forði wel wyrðe bæt hire acennednys

is she therefore well worthy that her birth arwurðlice gefreolsod sy honorably celebrated is

10 Mitchell's (1985: §1599) statement given in (i) seems to be an exaggeration at least in the present text.

(i) The OE verb is most commonly negated by the adverb ne immediately preceding it, no matter what the order of the other elements. The negated verb is normally in initial position in principal clauses in the prose .... Most of the exceptions involve personal pronoun subjects ....

Examples where negated verbs follow full noun subjects as shown in (ii) are not rare.

(ii) a. bæt folc ne cuðe ðara goda

the people not knew the benefits

'The people did not know the benefits'

b. ba apostoli ne dorston bodian pone soðan geleafan

the apostles not dared preach the true faith

'The apostles dared not preach the true faith' (ÆCHom I, 324. 4-5)

The page and line numbers of such examples other than (iia) and (iib) are given in (iii).

(iii) $266 / 31,280 / 3,282 / 19,382 / 2,420 / 23,512 / 13,588 / 7,594 / 25,596 / 31$, $610 / 11,616 / 29$ 
'Therefore, she is well worthy that her birth should be celebrated honorably'

(ÆCHom I. 354. 22-23)

b. Wearð peah pæt wif ða forspanen purh

was though the woman then seduced through

ðæs deofles lare

the devil's instigation

'However, the woman was seduced by the devil's instigation'

(ÆCHom I, 18. 8)

(25) unaccusative verbs (5 examples)

a. belimpð, hwæðere ðeah, seo hæðung to ðære hætan belongs nevertheless the heating to the heat 'Nevertheless, the heating belongs to the heat'

(ÆCHom I, 286. 3)

b. $(=(11 b))$

Beah ठa ungerim folces to

converted then countless-number folk's to

cristendome purh Petres lare

Christianity through Peter's teaching

'Then, countless numbers of people converted to Christianity through Peter's teaching'

(ÆCHom I, 374. 30-31)

c. Com ða se ðegen mid feo to ðam apostolum came then the thane with money to the apostles 'Then, the thane came to the apostles with the money'

(ÆCHom I, 316. 25)

d. $(=(11 \mathrm{a}))$

Comon eac sume ða ungeleafullan, mid nanum came also some the unbelieving with no wurðmynte, ac mid micclum graman honors but with great anger 'Some who do not believe also came with no honors, but with great anger'

(ÆCHom I, 206. 15-17)

e. Weox ða dæghwonlice Godes bodung waxed then daily God's preaching

'Then, the preaching of God waxed daily'

(ÆCHom I, 44. 18-19)

(26) verbs of saying (3 examples)

a. Cwyð nu Sc̄̄s Gregorius, pæt ...

says now St. Gregory that 
'St. Gregory now says that ...'

(ÆCHom I, 532. 29)

b. Cwyð nu sum mann ...

says now certain man

'A man says ...'

(ÆCHom I, 580. 13-14)

c. Secgað eac sume gedwæsmenn bæt ...

say also some foolish-men that

'Some foolish men also say that ...'( ÆCHom I, 100. 29)

Such restrictions are not imposed on NEG1 sentences. This is illustrated in (27) and (28).

(27) modal verbs

a. $(=(1 b))$

$\mathrm{Ne}$ mæg he nane gesceafta gescyppan

not can he no creatures create

'He can create no creatures'

(ÆCHom I, 16. 20-21)

b. Ne mæg ic minne feond lufian not can I my foe love

'I cannot love my foe'

(ÆCHom I, 54. 30)

(28) non-auxiliary verbs other than unaccusative verbs

a. Ne sohte Crist na ða modigan

not sought Christ not the proud

'Christ did not seek the proud' (ÆCHom I, 138. 7-8)

b. Ne bæd se blinda naðor ne goldes, ne

not prayed for the blind neither not gold nor seolfres

silver

'The blind man prayed neither for gold nor silver'

(ÆCHom I, 158. 20)

c. Ne het Crist him to lædan modigne stedan not commanded Christ him to lead proud steed mid gyldenum gerædum gefreatewodne with golden trappings adorned 'Christ did not command (them) to lead to him a proud steed adorned with golden trappings'

(ÆCHom I, 210. 14-15)

d. Ne bebead he his gingrum pæt ...

not enjoined he his disciples that

'He did not enjoin to his disciples that ...'

(ÆCHom I, 512. 21) 
e. Ne gedyde se sacerd pone man hreofligne oððe not made the priest the man leprous or unhreofligne unleprous

'The priest did not make the man leprous or unleprous'

(ÆCHom I, 124. 24)

The verbs in (28a) and (28b), respectively, take an accusative and genitive NP complements. (28c) involves a verb taking an infinitival clause and (28d) a verb with a dative object and a finite clause. The causative verb in (28e) is with a small clause complement.

As shown in (29)-(31), NEG1 constructions may also involve verbs which can be used in V1 constructions.

(29) wesan and weorðan 'be'

a. Ne bið se dom on nanum eorðlicum felda not is the doom on no earthly field gedemed deemed

'The doom will be deemed on no earthly field'

(ÆCHom I, 616. 25)

b. Ne wearð se Fæder mid menniscnysse befangen not was the Father with human-nature clothed 'The Father was not clothed with human nature'

(ÆCHom I, 284. 23)

(30) unaccusative verbs

a. Ne com he to ðy bæt he wære on mærlicum not came he so that he was on splendid cynesetle ahafen throne exalted

'He did not come to be exalted on a splendid throne'

(ÆCHom I, 82. 23-24)

b. Ne gewit ðeos mægð

not passes-away this tribe

'This tribe may not pass away' (ÆCHom I, 614. 33)

(31) verbs of saying

a. Ne cwæð na se Symeon pæt... not said not the Simeon that 'Simeon did not say that ...' (ÆCHom I, 146. 15-16)

b. Ne sægde pæt halige godspel pæt ... not said the holy gospel that 
'The holy godspel did not say that ...'

(ÆCHom I, 328. 17)

(32) is a list of verbs that are used in NEG1 constructions and the contexts in which they are used.

(32) a. with no complement

belifan 'remain,' gebiddan 'worship,' cuman 'come,' fleon 'flee,' gan 'go,' libban 'live,' glidan 'glide,' teon 'prosper,' gewitan 'pass away'

b. with an accusative NP

amierran 'injure,' asceotan 'shoot,' astyrian 'stir up,' bepæcan 'deceive,' cunnan 'know,' derian 'damage,' findan 'find,' forseon 'despise,' habban (nabban) 'have,' leornian 'learn,' (ge)lufian 'love,' mænan 'mean,' gemetan 'meet,' oncnawan 'understand,' ondrædan 'dread,' onwreon 'uncover,' secan 'search,' geseon 'see,' underfon 'obtain,' witan (nat) 'know,' wiðcweðan 'deny,' wyrcan 'work'

c. with a genitive NP

biddan 'pray,' cepan 'desire'

d. with a dative NP

leogan 'lie'

e. with a PP

awendan 'pass away,' becuman 'come,' feran 'go'

f. with genitive and accusative NPs

bidan 'ask'

g. with an accusative NP and a PP sendan 'send'

h. with a finite clause cweðan 'say,' secgan 'say,' wiðcweðan 'deny'

i. with a nonfinite clause geswican 'cease'

j. with a small clause gedon 'make'

k. with an accusative NP and a nonfinite clause geseon 'see'

1. with a dative NP and a finite clause bebeodan 'command'

m. with a dative NP and a nonfinite clause hatan 'command' 


\section{n. with a reporting clause \\ cweðan 'say'}

Note that wesan, weorðan 'be' and modal verbs are not included in the list.

It seems that there is no restriction imposed on verbs used in NEG1 constructions, which is in sharp contrast with cases of V1 constructions. This discrepancy between NEG1 and V1 constructions strongly suggests that they are different in character, which leads us to the conclusion that the V1 analysis of NEG1 constructions should be discarded. On the other hand, the V2 analysis correctly handles the lack of restriction on verbs used in NEG1 constructions. This analysis predicts that any verb can be used in NEG1 constructions just as any verb can be used in other V2 sentences and the prediction is borne out as we have just seen.

The remaining problem is why V-to-C movement takes place in the $\mathrm{V} 1$ constructions in (24)-(26) although the Spec $\mathrm{C}^{\prime}$ position in these examples is apparently empty. A speculative answer suggested here is that in these examples V-to-C movement is prompted by discourse cohesion and the principle in (4), repeated here as (33), is irrelevant. ${ }^{11}$

(33) V-to-C movement is triggered when Spec $\mathrm{C}^{\prime}$ position is filled.

In other words, I claim that V1 constructions in Old English share crucial properties with corresponding constructions in other Germanic languages. In Icelandic, for example, V1 declaratives as illustrated in (34) are analyzed as expressing strong discourse cohesion.

11 An alternative analysis, which is also able to maintain (33), is to assume (i).

(i) There is an empty narrative adverb in Old English (Ælfric's grammar) and it can be used only with the following verbs.
a. wesan/weorðan 'be;'
b. unaccusative verbs; and
c. verbs of saying.

The empty narrative adverb assumed here is an empty counterpart of narrative adverbs such as $n u$ 'now' and $\partial a$ 'then,' which are used to link the sentences where they occur with the preceding context. In this analysis the structure of V1 constructions is as in (ii), where ' $A D V$ ' is the empty narrative adverb.

(ii) [CP ADV [C' belimp [IP seo hæðung to ðære hætan]]] belongs the heating to the heat

In (ii) $\mathrm{V}$-to- $\mathrm{C}$ movement is triggered by the empty narrative adverb which occupies the Spec $C^{\prime}$ position.

Again, the unsolved question is why only those given in (i) are qualified as verbs which can be used with the empty narrative adverb. 
(34) Kom Ólafur seint heim. came Olaf late home 'Olaf came home late.'

(Sigurðsson (1990: 41))

This solution, however, raises another question why verbs affected by discourse cohesion are restricted to those given in (24)-(26). I leave this question open here but it might be relevant to point out that the verbs given in (24)-(26) roughly correspond to those used in "inversion" constructions in Present-day English as illustrated in (35)-(37).

(35) be

Examined today and found in good health was our nation's chief executive.

(Emonds (1976: 36))

(36) unaccusative verbs

a. In came John! (Emonds (1976: 29))

b. Down the street rolled the baby carriage!

(ibid.)

(37) say

'Please go away' said one child (Quirk et al. (1985: 1380))

The Present-day English facts show that the verbs singled out in (24)-(26) share common properties that are not possessed by other verbs, which weakly supports the present analysis.

\section{Conclusion}

In this article I have presented an analysis of NEG1 constructions in Old English. It has been demonstrated that the correct approach should assume the presence of an empty operator in the Spec $\mathrm{C}^{\prime}$ position and treat NEG1 constructions in parallel fashion with other V2 sentences. It has also been suggested that V-to-C movement in V1 constructions takes place for discourse cohesion in contrast to other cases, where V-to-C movement is triggered by an element in the Spec $\mathrm{C}^{\prime}$ position. The remaining problem is how to account for the restriction imposed on the type of verbs used in V1 constructions.

\section{REFERENCES}

Baker, Mark C. (1988) Incorporation: A Theory of Grammatical Function Changing, University of Chicago Press, Chicago.

Chomsky, Noam (1986) Barriers, MIT Press, Cambridge, MA. 
Chomsky, Noam (1991) "Some Notes on Economy of Derivation and Representation," Principles and Parameters in Comparative Grammar, ed. by Robert Freiden, 417-454, MIT Press, Cambridge, MA.

deHaan, Germen and Fred Weerman (1986) "Finiteness and Verb Fronting in

Frisian," Verb Second Phenomena in Germanic Languages, ed. by Hubert

Haider and Martin Prinzhorn, 77-110, Foris, Dordrecht.

Emonds, Joseph E. (1976) A Transformational Approach to English Syntax, Academic Press, New York.

Haeberli, Eric (1991) The NEG Criterion and Negative Concord, Mémoire de Licence, University of Geneva.

Haeberli, Eric and Liliane Haegeman (1995) "The Structure in Old English:

Evidence from Negative Concord," Journal of Linguistics 31, 81-108.

Haegeman, Liliane (1995) The Syntax of Negation, Cambridge University Press, Cambridge.

Holmberg, Anders (1986) Word Order and Syntactic Features in the Scandinavian Languages and English, Doctoral dissertation, University of Stockholm.

Holmberg, Anders and Christer Platzack (1995) The Role of Inflection in Scandinavian Syntax, Oxford University Press, Oxford.

Hulk, Aafke, and Ans van Kemenade (1995) "Verb Second, Pro-drop, Functional Projections and Language Change," Clause Structure and Language Change, ed. by Adrian Battye and Ian Roberts, 227-256, Oxford University Press, Oxford.

Ishikawa, Kazuhisa (1995) "A History of Not: The Change from a Phrase to a Head," English Linguistics 12, 197-221.

Kageyama, Taro (1992) "AGR in Old English To-Infinitives," Lingua 88, 91-128.

Kato, Kozo (1989) "SOV/SVO Gengo toshiteno Koeigo: Catholic Homilies ni mirareru Settyuu no 'nu' o megutte (Old English as an SOV/SVO Language with Special Reference to Clause-internal $\mathrm{Nu}$ in Catholic Homilies)," Ivy 22, 161-175.

Kato, Kozo (1995) "Dooshi-idou to Eigo no Touchi-koubun ni tsuiteRekishiteki ni (Verb Movement and Inversion Constructions in English-A Diachronic Approach)," paper presented at the 12th Annual Meeting of the Modern English Society.

Kemenade, Ans van (1985) "Old English Infinitival Complements and WestGermanic V-Raising," Papers from the 4th International Conference on English Historical Linguistics, ed. by Roger Eaton, Olga Fischer, Willem Koopman and Frederike van der Leek, 73-84, John Benjamins, Amsterdam.

Kemenade, Ans van (1987) Syntactic Case and Morphological Case in the History of English, Foris, Dordrecht.

Kiparsky, Paul (1995) "Indo-European Origins of Germanic Syntax," Clause Structure and Language Change, ed. by Adrian Battye and Ian Roberts, 
140-169, Oxford University Press, Oxford.

Koopman, Hilda (1984) The Syntax of Verbs, Foris, Dordrecht.

Koopman, Willem F. (1990) Word Order in Old English, with Special Reference to the Verb Phrase, Doctoral dissertation, University of Amsterdam.

Koopman, Willem F. (1992) "The Distribution of Verb Forms in Old English Subordinate Clauses," History of Englishes: New Methods and Interpretations in Historical Linguistics, ed. by Matti Rissanen, Ossi Ihalainen, Terttu Nevalainen, and Irma Taavitsainen, 319-335, Mouton de Gruyter, Berlin.

Mitchell, Bruce (1985) Old English Syntax, Clarendon Press, Oxford.

Müller, Gereon and Wolfgang Sternefeld (1993) "Improper Movement and Unambiguous Binding," Linguistic Inquiry 24, 461-507.

Ohkado, Masayuki (1989) "INFL and Negating Particles," Lingua 77, 1-12.

Ohkado, Masayuki (1996) "Subordinate Clauses in Old English," ms., OsakaKyoiku University.

Ouhalla, Jamal (1990) "Sentential Negation, Relativized Minimality and the Aspectual Status of Auxiliaries," Linguistic Review 7, 183-231.

Pintzuk, Susan (1991) Phrase Structures in Competition: Variation and Change in Old English Word Order, Doctoral dissertation, University of Pennsylvania.

Pintzuk, Susan (1993) "Verb Seconding in Old English: Verb Movement to Infl," The Linguistic Review 10, 5-35.

Platzack, Christer (1986) "The Position of the Finite Verb in Swedish," Verb Second Phenomena in Germanic Languages, ed. by Hubert Haider and Martin Prinzhorn, 27-47, Foris, Dordrecht.

Pollock, Jean-Yves (1989) "Verb Movement, Universal Grammar, and the Structure of IP," Linguistic Inquiry 20, 365-424.

Quirk, Randolph, Sidney Greenbaum, Geoffrey Leech, and Jan Svartvik (1985) A Comprehensive Grammar of the English Language, Longman, London.

Rizzi, Luigi (1990) "Speculations on Verb Second," Grammar in Progress, ed. by Joan Mascaró and Marina Nespor, 375-386, Foris, Dordrecht.

Roberts, Ian (1993) Verbs and Diachronic Syntax: A Comparative History of English and French, Kluwer, Dordrecht.

Safir, Ken. (1982) "Inflection Government and Inversion," The Linguistic Review 1, 417-467.

Saito, Shinji, Masao Okazaki, and Masaharu Shimada (1991) "On the Position of INFL in Old English," English Linguistics 8, 124-144.

Santorini, Beatrice (1989) The Generalization of the Verb-Second Constraint in the History of Yiddish, Doctoral dissertation, University of Pennsylvania.

Sigurð̌sson, Halldór Ármann (1990) "V1 Declaratives and Verb Raising in Icelandic," Syntax and Semantics 24: Modern Icelandic Syntax, ed. by Joan Maling and Annie Zaenen, 41-69, Academic Press, New York.

Tanaka, Tomoyuki (1994) "On the Realization of External Arguments in Infinitives," English Linguistics 11, 76-99. 
Taraldsen, Tarald (1986) "On Verb Second and the Functional Content of Syntactic Categories," Verb Second Phenomena in Germanic Languages, ed. by Hubert Haider and Martin Prinzhorn, 7-25, Foris, Dordrecht.

Thorpe, Benjamin (ed.) (1844) The Homilies of the Anglo-Saxon Church, The Elfric Society, London

Tomaselli, Alessandra (1990) "COMP" as a Licensing Head: An Argument Based on Cliticization," Grammar in Progress, ed. by Joan Mascaró and Marina Nespor, 433-445, Foris, Dordrecht.

Traugott, Elizabeth C. (1992) "Syntax," The Cambridge History of the English Language, Vol. I, ed. by Richard M. Hogg, 168-289, Cambridge University Press, Cambridge.

Travis, Lisa (1984) Parameters and Effects of Word Order Variation, Doctoral dissertation, MIT.

Vikner, Sten (1995) Verb Movement and Expletive Subjects in the Germanic Languages, Oxford University Press, Oxford.

Weerman, Fred (1989) The V2 Conspiracy, Foris, Dordrecht.

Zwart, Jan-Wouter (1993) Dutch Syntax, Doctoral dissertation, University of Groningen.

T470-02 Aichi-ken Nishikamo-gun

Miyoshi-cho Kurozawa

Ibomichi 1033 